\title{
WELL-BEING AT WORK IN PROCESSES OF ORGANIZATIONAL CHANGE: THE ROLE OF INFORMAL SOCIAL NETWORKS
}

\author{
ELISA M. B. AMORIM-RIBEIRO ${ }^{1}$ \\ (iD) https://orcid.org/0000-0002-4550-454X \\ ELAINE R. NEIVA ${ }^{2}$ \\ (iD) https://orcid.org/0000-0003-0503-3234 \\ MAGNO O. MACAMBIRA ${ }^{3}$ \\ (iD) https://orcid.org/0000-0002-6453-3020 \\ LEONARDO F. MARTINS ${ }^{1}$ \\ (iD) https://orcid.org/0000-0002-0941-6294
}

To cite this paper: Amorim-Ribeiro, E. M. B., Neiva, E. R., Macambira, M. O., \& Martins, L. F. (2022). Well-being at work in processes of organizational change: The role of informal social networks. Revista de Administração Mackenzie, 23(1), 1-26. doi:10.1590/1678-6971/eRAMG220125

Submission: June 15, 2019. Acceptance: Sept. 11, 2019.

1 Salgado de Oliveira University (Universo), Niterói, RJ, Brazil.

2 University of Brasília (UnB), Brasília, DF, Brazil.

3 State University of Feira de Santana (Uefs), Feira de Santana, BA, Brazil.

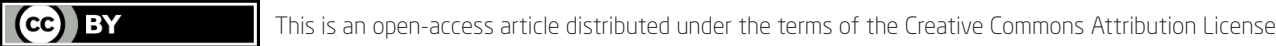

\footnotetext{
This paper may be copied, distributed, displayed, transmitted or adapted for any purpose, even commercially, if provided, in a clear and explicit way, the name of the journal, the edition, the year and the pages on which the paper was originally published, but not suggesting that RAM endorses paper reuse. This licensing term should be made explicit in cases of reuse or distribution to third parties.

Este artigo pode ser copiado, distribuído, exibido, transmitido ou adaptado para qualquer fim, mesmo que comercial, desde que citados, de forma clara e explícita, o nome da revista, a edição, o ano e as páginas nas quais o artigo foi publicado originalmente, mas sem sugerir que a RAM endosse a reutilização do artigo. Esse termo de licenciamento deve ser explicitado para os casos de reutilização ou distribuição para terceiros.
} 


\section{ABSTRACT}

Purpose: This study evaluates the role of social networks of support, information, and trust in well-being at work, regarding the positive and negative affects and professional fulfillment of workers immersed in processes of organizational change.

Originality/value: Organizational change is characterized as a dynamic process, constituted through relationships, immersed in a context of uncertainties. The mapping of relationships can help in understanding the information flows and the assessment of resource availability.

Design/methodology/approach: 151 professionals from a holding participated. This company undergoes changes in the scope of services offered and the organizational design. Links of support, information, and trust established according to the change processes were mapped. Associated with the network, the Well-Being at Work Scale was used. For data analysis, multiple regressions were used to construct explanatory models for well-being factors: fulfillment, positive and negative affects.

Findings: Variables in support and information social network analysis (SNA) composed the predictive model of well-being in the three models. Among the researched ties, the support and information ties were part of the predictive model of well-being. The metrics that reveal how many times the employee is indicated and indicates others, proximity to highly cited neighbors, degree of participation in cohesive subgroups, the degree to which they assume a central position in the subgroups are indicators of actors' positions capable of predicting well-being. The influence of the pattern of interaction between managers and employees should be considered in promoting well-being in organizations in the process of change.

\section{KEYWORDS}

Change in organizations. Social network analysis. Well-being at work. Support network. Information network. 


\section{INTRODUCTION}

Processes of organizational change are characterized by changes in organizational structures caused by interventions that impact the organization's results and the daily lives of its members (Neiva \& Paz, 2012; Woodman, 2014). These processes are dynamic (Jian, 2011; Schreyögg \& Sydow, 2011) and are the fabric of interpersonal relationships established by managers and employees. Organizational change, which is interactive by nature, is a nonlinear movement of advances and setbacks towards a specific direction (Woodman, 2014).

The mapping of interpersonal relationships in the context of organizational change can shed light on how collective action and perception contribute to or hinder leads to new ways of thinking, leading, and achieving organizational results (Brands, 2013). The use of social network analysis (SNA) associated with the field of organizational psychology has been able to make informal relationships in the organizational context visible (Ribeiro, Macambira, \& Neiva, 2017). More than that, understanding the pattern of daily interaction in organizations enables us to understand how these patterns favor or not the fulfillment of organizational results (Cross, Singer, Colella, Thomas, \& Silverstone, 2010, 2010).

SNA can be understood as a multidisciplinary paradigm that seeks to understand the patterns of ties that connect actors and their effects to actors and the social structure. The basic unit of analysis of SNA are the interactions, the resources exchanged, and the social structure built from these relationships (Borgatti \& Lopez-Kidwell, 2011). Most of the studies in organizational psychology associated with SNA are based on the theoretical network flow model, in which a flow is a latent variable that can be measured from a link pattern between actors.

Borgatti and Lopez-Kidwell (2011) outlined the proposition of the flow model to integrate classical theories in SNA, such as the strength-of-weak-ties theory, the theory of social capital, and the theory of structural holes. Underlying this model, the authors highlight two central functions of social networks: the access or restriction to available social capital and promotion of homogeneity using mechanisms of social influence. In the first one, the network is understood as a space for providing resources that are accessible to better positioned or more central actors. In addressing the actors' positions in the network and processes of organizational change, Wichmann, Carter, and Kaufmann (2015) point out the relationship between centrality 
in the social network, proactive characteristics of actors, and the potential for adopting new behaviors.

The mechanism of the flow model, called social influence (Burt \& Merluzzi, 2014), explains that individuals tend to maintain beliefs, attitudes, and behaviors like those of their close social connections. Many studies highlight the important role the peer proximity (Yamanis, Fisher, Moody, \& Kajula, 2015) and the overall network structure (De, Cox, Boivin, Platt, \& Jolly, 2007) can play in acquiring new behaviors (Mulawa et al., 2016). In addition, SNA enables us to assess whether the overall structure of interactions allows access to the information and tools needed to implement new work processes. In this sense, SNA can assume a strategic place for change management by allowing the identification of influential actors who learn new behaviors and accept or refuse change.

This strategic place has been observed in studies that highlight the important role of the network macrostructure through which mechanisms of social influence, proximity, and similarity between peers occur. These mechanisms act in the diffusion of descriptive norms and play a fundamental role in the formation and maintenance of favorable or unfavorable behaviors to change (Ajilore, 2015; Barrington et al., 2009; Burt \& Merluzzi, 2014; De et al., 2007; Mulawa et al., 2016; Yamanis et al., 2015). Another important factor in change processes is the role of building bridges between departmental units, which is a task assigned to formal department leaders. The density of the leaders' connections with their followers and with leaders from other departments within the network are crucial factors for adopting desired behaviors during the process of change (Tenkasi \& Chesmore, 2003).

Establishing strong ties with influential members of the organization who are undecided about change provides the change agent with an affective basis for co-opting them. This process of co-optation increases the likelihood that the organization will embrace change. On the other hand, strong ties with potentially influential but resilient members of the organization are an effective means of co-optation only when change diverges little from institutionalized practices. With changes that are more divergent from institutionalized practices, the advantages of strong ties to resisters occur when change agents are weaker and can become obstacles that reduce the likelihood of change being adopted (Battilana \& Casciaro, 2013).

Informal social networks also impact creative (Dokko, Kane, \& Tortoriello, 2014) and innovative behaviors (Wong \& Boh, 2014). They can also influence the degree of organizational commitment, entrenchment, and consent (Macambira, Bastos, \& Rossoni, 2015), which, in turn, impacts workers' acceptance of supportive behaviors for change (Lysova, Richardson, 
Khapova, \& Jansen, 2015). They help to form judgments about new aspects of work based on the judgments of their co-workers (Kehoe \& Wright, 2013) and demonstrate how management action is important for adopting innovative behaviors (Gubbins \& Dooley, 2014; Wong \& Boh, 2014).

Advances in research show that weak ties, structural holes (Maciel \& Chaves, 2017), cognition, and personality are prominent themes (Cross et al., 2013) whose results indicate the advantage of the quality of ties in the network size to promote change in the behaviors and cognition of individuals. While close ties can hinder change (Battilana \& Casciaro, 2013), strong ties correlated with more proactive and pro-change actors who contribute to successful organizational change (Teixeira \& Verhine, 2014). Battilana and Casciaro (2013) concluded that social ties and relationships can be crucial for successful change as they provide the substrate for co-opting individuals to support the process.

Some leaders still underestimate the central role individuals play in the process of change (Choi, 2011, Cross et al., 2013), others are "champions of change" and seek to identify employees who support change and promote change in peers (Khatoon \& Farooq, 2014; Lysova et al., 2015). In this scenario, change processes can intensify intergroup relations and increase the political character of change through interactions marked by power struggles between groups for and against change (Pichault \& Schoenaers, 2003). In a context of political disputes, uncertainties and expectations are a characteristic of processes of change and employees may experience stress and illness resulting from feelings of denial (Franco, Neiva, Nery, \& Demo, 2016).

We know that the working conditions play an important role in the degree of stress experienced by the worker. A longitudinal study conducted by Marchand, Demers, and Durand (2005) found that job insecurity and greater decision-making power are important factors for increasing the risk of psychological distress. In addition to these findings, the study demonstrates that occupational structure plays a limited role when considering daily life structures and personality elements.

Many studies on social relationships and well-being still address illness measures to measure individual well-being. In general, these studies report that the type of relationship, degree of closeness, and frequency of contact in informal social networks influence the amount of effort undertaken to minimize illness in informal social networks (Vassilev et al., 2013). As an example, the study by Luria and Kalish (2013) on the types of relationships found different prediction results depending on the nature of the tie, whether it was a collaborative or a friendship tie. In the collaboration network, the most cited actors received high scores for engagement and performance 
when faced with stressful situations. In the friendship network, non-redundant actors, that is, those who were not part of a closed subgroup, received better scores for engagement, performance under stress and leadership.

In general, few studies prioritize well-being scales over illness scales when associating social network analysis and well-being. Research has suggested associations between subjective well-being and characteristics of informal social networks, such as network size. Among them, Borgatti, Everett, and Johnson (2013) and Borgatti, Mehra, Brass, and Labianca (2009) identified that the degree of community urbanism reduced the social network density of actors, and it was negatively related to satisfaction and general well-being measures of these communities.

The effect of social status on the network and personal connections has presented different results in friendship and counseling networks and in different, more competitive, or collaborative practices in organizations (Dabos $\&$ Rousseau, 2013). To conduct a study using the structural equation model, Wang (2016) identified that perceived social support partially mediated the relationship between network size and subjective well-being. Some studies in the organizational context point to an overload of central actors and their perception of the lack of rewards for their efforts that result in requests to leave the team (Soltis, Agneessens, Sasovova \& Labianca, 2013). Characteristics of network members (type of relationship, proximity, and frequency of contact) influence the amount of effort undertaken to minimize illness in informal social networks (Vassilev et al., 2013).

The impact of social networks on individual well-being can also be analyzed from the standpoint of negative relationships in the context of social networks in organizations. Based on the negative asymmetry argument, negative relationships, unlike positive relationships, can negatively affect well-being at work (Labianca \& Brass, 2006). Social network data related to information exchange, client referrals, and working together contributed to mental and emotional health, or stress levels, in a group of Australian rural workers (Fuller et al., 2007). In their study, the influence of the network, prominence, and intermediate status on well-being indicators were evidenced (Fuller et al., 2007).

Considering the arguments above, it may be assumed that the characteristics of the informal social network can directly affect the well-being of individuals and their work teams, especially during the processes of organizational change. Factors such as network characteristics, strength of ties, level of information obtained, and source of information can affect workers' affective, cognitive, and emotional reactions, which may impact their well-being. 
In order to explore the dynamics between the pattern of employee interaction and their indicators of well-being, the study aimed to identify associations between employee positions in the informal social network and well-being at work. Based on the findings that combine behavioral change and patterns of association in different types of networks (Conde \& Farias, 2016), the predictive power of three types of ties with workers' well-being were assessed: support, information, and trust. In addition, for each type of tie, the predictive effects of network metrics on workers' well-being are assessed using three main dimensions: positive affect, negative affect, and professional fulfillment (Demo \& Paschoal, 2016; Paschoal \& Tamayo, 2008).

\section{METHOD}

This exploratory study aimed to identify the contribution of support network measures, information, and confidence in workers' well-being in each of the three dimensions: positive affect, negative affect, and professional fulfillment.

\subsection{Study participants}

A total of 256 employees from a transport holding company were invited to participate in the study. Of the 256 questionnaires submitted, 151 were answered, representing $58.9 \%$ of the total. The sample was predominantly composed of men $(73.3 \%)$. As for education, $44 \%$ of participants have a high school degree, $29 \%$ finished higher education, $19 \%$ are enrolled in higher education, $17 \%$ have a graduate degree, and $16 \%$ finished elementary school. A total of 36 participants hold leadership positions, of which 27 participants were men and 9 were women. The employees belong to six companies of the holding, and they occupy 37 management, administrative, financial, and operational job positions. A more significant number of participants worked in bus agencies, approximately $40 \%$ of the total sample.

\subsection{Procedures and instruments}

Data collection was performed at a holding company based in Brazil. These companies of the holding offer transport service. Although the processes of change regarding the formation and aggregation of new companies have been in process since 2009, remarkable change processes took place between 2018 and 2019. These processes refer to the increase in the services' scope, including logistics, charter, and tourism services. In addition, the company 
is undergoing processes of organizational change in several areas, such as the creation of a logistics unit, integration of human resources units and personnel department. The company's headquarters has also moved to another state.

The instruments were applied to the employees of some holding units who received a link by e-mail to assess the electronic form. Before answering the proposed scales, the participant read the informed consent and proceeded only after being aware and agreeing to the terms presented.

The Well-Being at Work Scale (Demo \& Paschoal, 2016; Paschoal \& Tamayo, 2008), consisting of three factors (positive affect, negative affect, and fulfillment) is composed of 29 items and the reliability index is above 0.90. Exploratory and confirmatory factor analyses indicated three factors with Cronbach's alpha values of $0.91,0.86$ and 0.87 and factor loadings above 0.45 . The fit measures of confirmatory factor analysis were satisfactory $\left(c^{2} / \mathrm{df}=2.02 ; \mathrm{TLI}=0.91 ; \mathrm{CFI}=0.92 ; \mathrm{GFI}=0.90 ; \mathrm{RMSEA}=0.07\right)$.

To map the network, employees were asked to indicate up to five co-workers with whom they established contact for support, information or to express what they thought about the processes of change. Using these terms, the support, information, and trust networks were mapped, respectively. In addition, for each cited co-worker, the participant assessed the closeness of the relationship using a scale from 1 (not so close) to 5 (very close).

\subsection{Data analysis}

For the analysis of the measures in the SNA, the participants' answers about the relationships with their peers were organized in adjacency matrices that enabled the analysis of centrality data and grouping for each actor in the network. The measures of degree, indegree and outdegree centrality, authority, eigenvector, modularity class, and clustering coefficient were generated using the Gephi software (Bastian, Heymann, \& Jacomy, 2009) for each type of mapped network. Figure 2.3.1 shows the meaning of each measure.

Data on well-being variables at work were defined as outcomes (dependent variables) and the network metrics as potentially explanatory variables on well-being, together with control variables that characterize socio-demographic aspects (gender, education, age) and characteristics (length of service, company, hierarchical level) that were established as independent variables. Considering the exploratory nature of the study's objectives and the complexity regarding the number of metric values from the networks, an automatic regression analysis was adopted for choosing the significance of the variables. 
(Figure 2.3.1)

MEANING OF THE METRIC ANALYSIS OF THE SOCIAL NETWORKS

\begin{tabular}{|c|c|}
\hline Measure & Meaning \\
\hline Indegree & Quantity of citations received by a certain actor (Hanneman \& Riddle, 2011). \\
\hline Outdegree & Quantity of citations given by a certain actor (Hanneman \& Riddle, 2011). \\
\hline Degree & Sum of Indegree and Outdegree (Hanneman \& Riddle, 2011). \\
\hline Bridging & $\begin{array}{l}\text { Identifies actors who have an important linkage between two or more portions of } \\
\text { a network (Everett \& Valente, 2016). }\end{array}$ \\
\hline Authority & More important actors in specific subgroups in the network (Lü et al., 2016). \\
\hline Eigenvector & $\begin{array}{l}\text { The score of the actor is proportional to the sum of scores of the neighbors } \\
\text { (Borgatti \& Halgin, 2011). }\end{array}$ \\
\hline $\begin{array}{l}\text { Modularity } \\
\text { class }\end{array}$ & $\begin{array}{l}\text { A measure of ego that informs the quantity of communities in which each actor } \\
\text { takes part in (Newman, 2006). }\end{array}$ \\
\hline $\begin{array}{l}\text { Clustering } \\
\text { coefficient }\end{array}$ & $\begin{array}{l}\text { A measure of ego that informs the proportion of in which each node participates in } \\
\text { densely tied subgroups (Katona, Zubcsek, \& Sarvary, 2011). }\end{array}$ \\
\hline
\end{tabular}

Source: Elaborated by the authors.

The automatic regression method tests all possible combinations of a set of predictors using a predefined criterion to rank these combinations in an order by criteria that optimizes the model's prediction ability against one or more criteria variables. Considering that the number of possible combinations grows rapidly in relation to the models with higher values of explained variance, sample size adjustment, and the number of predictors (adjusted R2), an indicator is used to classify the models. Additionally, a recategorization algorithm is used to test relationships between subgroups formed by the variables that optimize the explanatory capacity of the model. the Akaike Information Criterion (AIC) for minimization, which estimates the relative quality of the models, was adopted as an objective function.

The set of possible models, considering the combinations among the variables and their recategorizations, which was automatically made by the adopted algorithm, were evaluated by the AIC and the best subsets formed by the explanatory and control variables were selected as the best model. It is noteworthy that the choice of the final model also considers whether the recategorization produced by the algorithm makes sense in theoretical terms. The variables related to the metric generated from informal social networks were analyzed using standard multiple regressions. 
The following assumptions for regression were analyzed using residual plots, normal probability plots, and statistical tests: phenomenon linearity, the constant variance of the error terms (homoscedasticity), independence of error terms, and normality of error term distribution. Finally, multicollinearity and singularity analyses did not reveal any problems in the researched sample, i.e., tolerance values were greater than 0.1 and variance inflation factor (VIF) was lower than 10.0 (Tabachnick \& Fidell, 2013).

\section{RESULTS}

This section begins by presenting the descriptive data of the well-being scores distributed in the three following factors: positive affect, negative affect, and professional fulfillment. This distribution, in turn, is shown by the demographic variables, namely: gender, education, company of origin, assumption of leadership or subordinate position, and overall calculation (Figure 3.1).

Although the well-being scale is answered on a 1-5-point scale (not at all too extremely), the data described in Figure 2.3.1 were transformed into z-scores. By standardizing the scales based on the mean of the zero scores and the standard deviation in one unit for each of the subscales, comparing them was easier. When men and women in the sample were compared, men showed more favorable results in the three dimensions of the scale: higher positive affect, lower negative affect, and higher professional fulfillment.

When comparing the level of education, employees with incomplete higher education degrees presented the lowest level of well-being in all factors evaluated: low positive affect, high negative affect, and low degree of professional fulfillment. Workers with elementary school, on the other hand, presented the most favorable well-being indices: high positive affect (0.3), lower mean negative affect $(-0.4)$, and higher mean professional fulfillment (0.4). Among the companies participating in the holding company, workers in companies $\mathrm{D}$ and $\mathrm{E}$ presented more significant well-being indices, while workers in companies A and F presented less favorable indicators for well-being at work. When comparing the assumption of leadership, leaders presented higher fulfillment scores and affective well-being. 


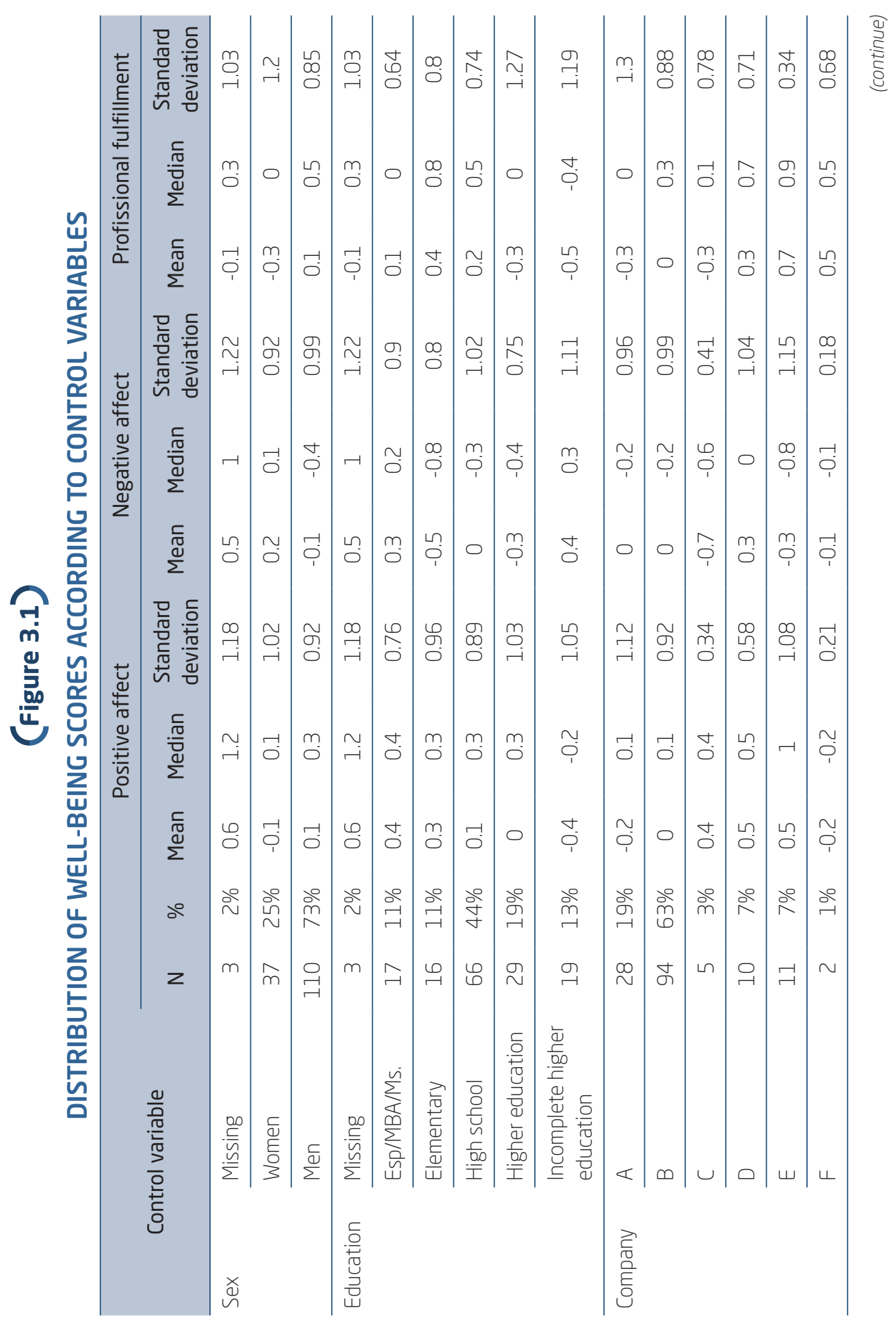




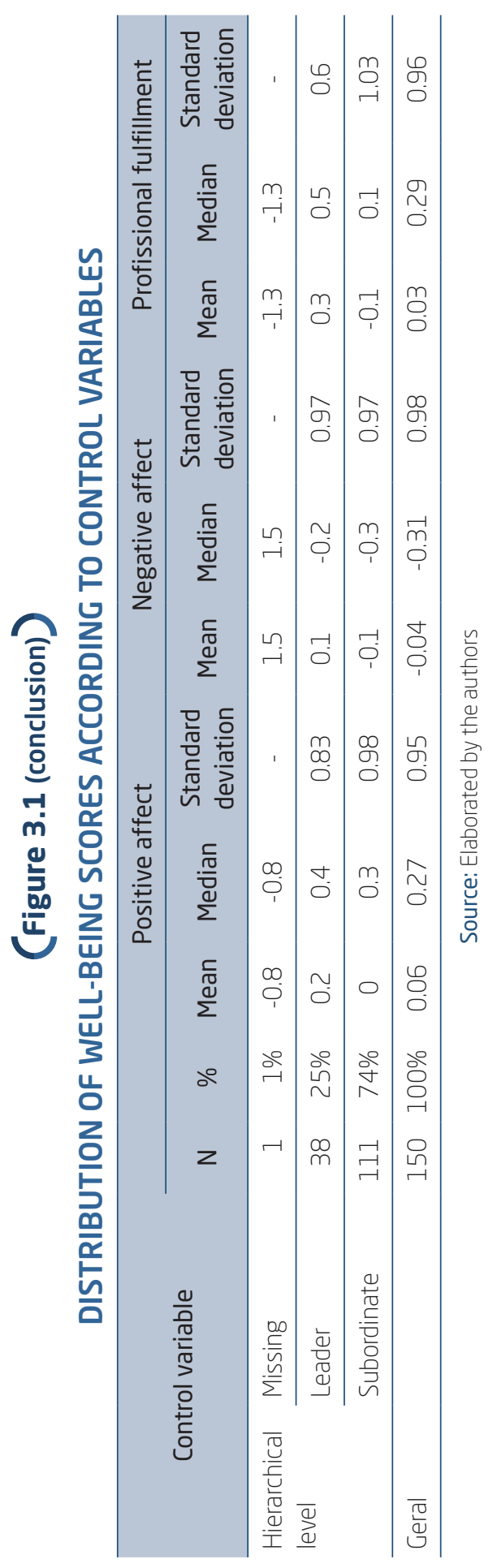


From this point on, three predictive models are presented for each of the well-being factors in the following sequence: professional fulfillment, positive affect, and negative affect. In addition to the socio-demographic data shown in Figure 3.1, the social networking variables described in the method were also tested. For each of the three models presented, we will inform which network variables were established as predictors and from which type of network (support, information, and trust).

\subsection{Professional fulfillment}

The final model for fulfillment, a dimension of well-being at work, explained $22.3 \%$ of the variance of professional fulfillment scores (adjusted $\mathrm{R} 2=0.223 ; \mathrm{F}(13.136)=4.6 ; \mathrm{p}<0.001)$, using the following equation:

$$
\begin{aligned}
Y_{\text {profissional fulfillment }} & =0.64 X_{\text {Company Subset A }}-0.53 X_{\text {Company Subset B }}-7.52 X_{\text {Eigenvector Information }} \\
& -0.43 X_{\text {Education Subset A }}+3.60 X_{\text {Coef. Clustering Information }}+0.25 X_{\text {Indegree Information }} \\
& -1.54 X_{\text {Coef. Clustering support }}
\end{aligned}
$$

For this first model, linear regression enabled us to identify the relevant metric related to the ties established when searching for information and support (Figure 3.1.1).

The most influential network measurements in this model was the information network. One of the most important metric values was the eigenvector $(B=-7.522 ; t(9)=-3.65 ; p<0.001)$, with the power to predict decrease in the fulfillment factor. Each participant's eigenvector centrality is based on the sum of the neighbors' scores in the network. This result indicates that the closer a collaborator is to other highly cited collaborators, the lower is professional fulfillment.

The measures of clustering coefficient $(B=3.6 ; t(9)=3.42 ; \mathrm{p}<0.001)$ and indegree centrality $(\mathrm{B}=0.25 ; \mathrm{t}(9)=2.01 ; \mathrm{p}<0.046)$ predict the increase in the fulfillment scores. The first metric, clustering coefficient, informs the degree of participation in a highly linked group. The result suggests that the higher the employee's participation in a closed subgroup (information network), the greater is the degree of professional fulfillment. The increase in the scores in the dimension of professional fulfillment is also predicted by the number of citations that the employee receives: the more others cite the employee, the greater the possibility of experiencing well-being due to increased professional fulfillment. 
In the support network, the metric for clustering coefficient $(B=-1.54$; $\mathrm{t}(9)=-2.54 ; \mathrm{p}<0.012)$ indicates an opposite trend as it indicates a decrease in the fulfillment scores. The existence of the same metric indicating opposite trends is analyzed in the discussion section of this paper. Although not significant, the authority index also composes the network variables framework of the predictive model, and it can predict the increase in the fulfillment scores at work $(B=5.89 ; \mathrm{t}(9)=1.57 ; \mathrm{p}<0.119)$. A high metric score for authority means that the employee has a central position in the subgroup of which he/she is a member.

The control variables of origin, education, and leadership (not significant) for companies present predictive capacity in the model for the dimension of professional fulfillment. The subset A of companies and the assumption of leadership position can predict an increase in well-being. The subset $\mathrm{B}$ of companies and the subset $\mathrm{A}$ of education can predict a reduction in the fulfillment factor. This subset A of education consisted of collaborators with incomplete and complete high education degrees.

(Figure 3.1.1)

FINAL MODEL FOR THE DIMENSION OF FULFILLMENT

\begin{tabular}{|c|c|c|c|c|c|c|c|}
\hline \multirow{2}{*}{ Model term } & \multirow{2}{*}{ Coefficient } & \multirow{2}{*}{$\begin{array}{c}\text { Standard } \\
\text { error }\end{array}$} & \multirow{2}{*}{$\mathrm{t}$} & \multirow{2}{*}{ Sig. } & \multicolumn{2}{|c|}{$\begin{array}{l}\text { 95\% confidence } \\
\text { interval }\end{array}$} & \multirow{2}{*}{ Relevance } \\
\hline & & & & & Lower & Higher & \\
\hline Company - subset A & 0.639 & 0.271 & 2.36 & 0.02 & 0.104 & 1.175 & 0.24 \\
\hline Company - subset B & -0.529 & 0.185 & -2.862 & 0.005 & -0.894 & -0.163 & 0.24 \\
\hline Eigenvector - information & -7.522 & 2.006 & -3.75 & 0 & -11.488 & -3.557 & 0.213 \\
\hline $\begin{array}{l}\text { Coefficient of information } \\
\text { clustering }\end{array}$ & 3.602 & 1.051 & 3.427 & 0.001 & 1.524 & 5.68 & 0.178 \\
\hline Education subset $A$ & -0.429 & 0.151 & 3.427 & 0.001 & 1.524 & 5.68 & 0.178 \\
\hline $\begin{array}{l}\text { Coefficient of support } \\
\text { clustering }\end{array}$ & -1.542 & 0.608 & -2.537 & 0.012 & -2.743 & -0.34 & 0.098 \\
\hline Indegree - information & 0.25 & 0.125 & 2.009 & 0.046 & 0.004 & 0.496 & 0.061 \\
\hline Leadership position & 0.323 & 0.177 & 1.825 & 0.07 & -0.027 & 0.672 & 0.051 \\
\hline Authority support & 5.892 & 3.761 & 1.567 & 0.119 & -1.543 & 13.328 & 0.037 \\
\hline
\end{tabular}

Source: Elaborated by the authors. 


\subsection{Positive affect}

The final positive affect model explained only $12 \%$ of the variance of positive affect scores (adjusted R2 $=0.12 ; \mathrm{F}(5.144)=5.04 ; \mathrm{p}<0.001$ ), using the equation below:

$$
\begin{aligned}
Y_{\text {positive affect }} & =0.52 X_{\text {Company Subset A }}-7.2 X_{\text {Coef. Authority support }}-0.23 X_{\text {Bridging Coef. Information }} \\
& +0.02 X_{\text {Age }}
\end{aligned}
$$

For this second metric model, linear regression revealed information and supportive networks as relevant (Figure 3.2.1).

The authority metric in the supportive network $(B=7.16$; $t(5)=2.35$; $\mathrm{p}<0.020)$, central in the subgroup of origin, can predict an increase in positive affect. The bridging coefficient in the information network ( $\mathrm{B}=$ $-0.23 ; \mathrm{t}(5)=-2.26 ; \mathrm{p}<0.025)$ indicates a decrease in the positive effect factor scores. Employees with the highest rates of bridging coefficient are those who function as bridges, that is, they are crucial connectors in social networks.

The control variables of origin (subset A) and age for the company also had the potential to predict increase in positive affect, while admission time pointed to a reduction in positive affect.

\section{(Figure 3.2.1)}

\begin{tabular}{|c|c|c|c|c|c|c|c|}
\hline \multirow{2}{*}{ Model term } & \multirow{2}{*}{ Coefficient } & \multirow{2}{*}{$\begin{array}{l}\text { Standard } \\
\text { error }\end{array}$} & \multirow{2}{*}{$\mathrm{t}$} & \multirow{2}{*}{ Sig. } & \multicolumn{2}{|c|}{$\begin{array}{l}95 \% \text { confidence } \\
\text { interval }\end{array}$} & \multirow{2}{*}{ Relevance } \\
\hline & & & & & Lower & Higher & \\
\hline Company subset A & 0.516 & 0.195 & 2.652 & 0.009 & 0.131 & 0.901 & 0.24 \\
\hline Admission time & 0 & 0 & -2.578 & 0.011 & 0 & 0 & 0.227 \\
\hline $\begin{array}{l}\text { Coefficient of authority - } \\
\text { support }\end{array}$ & 7.162 & 3.053 & 2.346 & 0.02 & 1.127 & 13.196 & 0.188 \\
\hline $\begin{array}{l}\text { Bridging coefficient - } \\
\text { information }\end{array}$ & 7.162 & 3.053 & 2.346 & 0.02 & 1.127 & 13.196 & 0.188 \\
\hline Age & 0.018 & 0.008 & 2.225 & 0.028 & 0.002 & 0.034 & 0.169 \\
\hline
\end{tabular}

FINAL MODEL FOR THE DIMENSION OF POSITIVE AFFECT

Source: Elaborated by the authors. 


\subsection{Negative affect}

The predictive model found for the dimension of well-being, negative affect, was the least explanatory potential of network metric among the three well-being factors (Figure 3.3.1). This third model explained only $11.7 \%$ of the variance of negative affect scores (adjusted R2 $=0.117$; $\mathrm{F}(6.143)=4.30 ; \mathrm{p}<0.001)$, using the model below:

$$
\begin{aligned}
Y_{\text {negative affect }} & =0.48 X_{\text {Education Subset A }}+0.84 X_{\text {Education Subset B }}+0.25 X_{\text {Degree Support }} \\
& -3.72 X_{\text {Eigenvecto Support }}-0.34 X_{\text {Sex }}
\end{aligned}
$$

In the support network, degree centrality $(B=0.25 ; \mathrm{t}(6)=2.35 ; \mathrm{p}<$ $0.020)$ predicts increase in negative affect. The degree centrality is the sum of the number of actors that the contributor cited and the number of times the contributor was cited. Eigenvector centrality of $(B=-3.72 ; t(6)=-1.94$; $\mathrm{p}<0.054)$, which informs how many neighbors of the employee are central, can indicate a decrease in negative affect.

In the information network, the metric that integrates the model is the modularity class $(B=-0.03 ; t(6)=-1.79 ; p<0.001)$, which is potentially capable of indicating a reduction in negative affect. Modularity class indicates in how many cohesive subgroups the employee participates. In this sense, the data indicates that the presence in more than one cohesive subgroup may help to reduce negative affect.

(Figure 3.3.1)

FINAL MODEL FOR THE DIMENSION OF NEGATIVE AFFECTS

\begin{tabular}{lcccccccc}
\hline \multirow{2}{*}{ Model term } & Coefficient & $\begin{array}{c}\text { Standard } \\
\text { error }\end{array}$ & $\mathrm{t}$ & Sig. & $\begin{array}{c}\text { 95\% confidence } \\
\text { interval }\end{array}$ & Relevance \\
\cline { 1 - 4 } & & & & & Lower & Higher & \\
\hline Education - subset A & 0.481 & 0.183 & 2.628 & 0.01 & 0.119 & 0.843 & 0.51 \\
\hline Education - subset B & 0.843 & 0.207 & 4.063 & 0 & 0.433 & 1.253 & 0.51 \\
\hline Degree of support & 0.253 & 0.107 & 2.35 & 0.02 & 0.04 & 0.465 & 0.167 \\
\hline Eigenvector of support & -3.718 & 1.917 & -1.939 & 0.054 & -7.508 & 0.071 & 0.114 \\
\hline Sex & -0.341 & 0.176 & -1.936 & 0.055 & -0.69 & 0.007 & 0.113 \\
\hline Modularity class of & -0.032 & 0.018 & -1.788 & 0.076 & -0.068 & 0.003 & 0.097 \\
information & & & & & & & & \\
\hline
\end{tabular}


This study aimed to investigate associations between employee positions in different social networks and well-being at work. To achieve this goal, we identified three predictive models for each of the well-being dimensions. In these models, we test the predictive power of information, support and trust connections, and their respective metric values based on the position of the actors in each network mapped.

Among the three dimensions of well-being researched (professional fulfillment, positive and negative affects), the position of actors in the networks predicted professional fulfillment better. Networks formed as a result of seeking support and information during processes of change were able to influence well-being scores in the three dimensions studied. The metric that reveals the number of times the employee is cited and cites other co-workers, the proximity of the employee to highly cited neighbors, the degree of participation in cohesive subgroups, and the degree to which they assume a central position in the subgroups to which they belong were indicators of the positions of actors for predicting well-being.

\section{DISCUSSION}

Comparison between predictor models for each well-being factor indicates that the social network variables analyzed have a higher predictive potential relative to the fulfillment factor. The fact that the content of the fulfillment items (other than those of negative affect and positive affect) are reportedly associated with work activity (companies) may have contributed to this result. In addition, the questions that generated social information, support, and trust networks referred directly to co-workers.

The nature of the tie resulted in distinct prediction results, as observed in the study by Luria and Kalish (2013). The positions assumed by the actors in the information and support networks were predictors of well-being in the three models generated for the dimensions of fulfillment, positive affect, and negative affect. There was an expectation that all three types of ties would be present in the predictive models, mainly the confidence tie. To generate this network, we asked the study participants to refer co-workers with whom they could talk about the processes of change. This tie was expected to be a significant predictor of well-being by representing connections with trust relationships, allegedly stronger ties and providers of social support. At the same time, we think that this is a less tangible tie and more influenced by the judgment of the nature of peer interactions rather than by 
how they express themselves in everyday work situations. In the support and information networks, however, exchanges are more tangible, in the sense that they can be revealed through verbal communication processes and daily supportive behaviors in the work context. This leads us to reflect that the contexts of change that require quick and effective access to information, as well as access to co-workers to assist the adoption of new behaviors, promote better well-being when compared to finding someone to talk to about one's own thoughts.

Regarding the positions assumed in the networks, the negative prediction of positive affect for actors with a high degree of bridging centrality in the information network called our attention. This position implies establishing crucial connections in the network. In contexts of change, establishing bridges between different subgroups and being responsible for the nondisintegration of these subgroups is related to the decrease in positive affect. This finding points to a potential overload of the collaborator in the network because he/she is mediating probable political disputes between favorable or unfavorable groups to the change in the organization, as Pichault and Schoenaers (2003) point out. The bridging position, in this case, places the employee in a position of management and restricts expectations and uncertainties, which Franco et al. (2016) point out as possible factors for reducing the worker's well-being. Along with this, being in this position also implies greater decision power, which is an element associated with increased stress levels (Marchand et al., 2005). Further studies should evaluate whether these bridge actors have leadership positions because if they do not, perception of lack of rewards (Soltis et al., 2013) for their efforts can contribute to reducing positive affect.

The phenomena related to group and intergroup processes seem to be relevant for promoting well-being in situations of organizational change. The predictive power of the authority position for affective well-being and fulfillment indicates that central actors in local subgroups are more likely to experience well-being at work. This may be related to the increased importance of the role of these actors as local influencers, who are now legitimized by the subgroup and have a greater influence on daily work.

Being a member of subgroups with a high degree of cohesion, a position indicated by the clustering coefficient, predicts an increase in the fulfillment factor in the information network. Cohesive subgroups are formed by a group of actors with high proximity through mutual ties. This setting results in quick access to information available in the subgroup, homogeneity of beliefs, and low possibility of being influenced by the surroundings (Freeman, 
2011). The promotion of the fulfillment factor at work may be related to the availability of information related to the processes of change.

In opposition, the same coefficient in the support network that was part of the predictive model indicated a decrease in the fulfillment factor. Cohesive subgroups also have the disadvantage of providing little or no access to members of external subgroups. This may represent a redundant flow of resources that becomes detrimental to learning and understanding new work processes. In addition, this contradiction may represent little semantic specificity of the term that generated the support network: "Cite co-workers who supported you during the process of change". Many interpretation possibilities of the definition of support may have been responsible for this result.

Still reflecting on the role of subgroups in promoting well-being, the modularity class measure of the information network was part of the explanatory model for revealing the decrease in negative affect. Modularity, understood at the actor level, is a measure that indicates to what extent each actor establishes intragroup ties compared to connections with members of external groups. The result indicates that the more the actor establishes intragroup relations, the lower is the proportion of negative affect.

\section{CONCLUSION}

Workers' positions in the information and support networks were part of the predictive models of the three components of well-being at work: fulfillment, positive affect, and negative affect. The type of tie mapped implied different panoramas and predictive power of SNA metric.

The decrease in well-being at work was associated with the assumption of central linkage in the information network (bridging centrality) and in the support network (degree of centrality). The promotion of well-being at work was associated with the degree of participation and influence in cohesive subgroups in the information network. In addition, increased well-being at work was also associated with the proximity of central actors (eigenvector centrality). This association can be explained by the access to functional and consistent information that facilitates adaptation to organizational changes without overload and responsibility falling on the central connectors.

The potential predictor of subgroup measures such as modularity and clustering coefficient draws attention to the importance of intra and intergroup processes in promoting or decreasing well-being in processes of change in organizations. The group may represent a place of comfort due to the homogeneity of beliefs and quick access to information, but may also 
imply a scarcity of possibilities due to the redundancy of available resources and resistance to the surroundings. Resistance promoted by the predominance of reciprocal and endogenous connections in subgroups can be a barrier to adopting organizational changes (Battilana \& Casciaro, 2013).

Further studies should assess the role of macro and medium structural features of the network, such as size, density, general centralization, and configuration of subgroups for promoting well-being at work. In addition, using valued networks can increase score variability and allow further refinement of the predictor models. Implementing research programs that consider these characteristics could further advance if multilevel models that consider, as in the present example, the dynamics of these phenomena at different levels are used. Considering these aspects, it is also important to highlight the limitations related to the generalization of the results, and it would be necessary to replicate this model in different contexts.

\section{BEM-ESTAR NO TRABALHO EM PROCESSOS DE MUDANÇA ORGANIZACIONAL: O PAPEL DAS REDES SOCIAIS INFORMAIS}

\section{RESUMO}

Objetivo: Este estudo avalia o papel das redes de apoio, informação e confiança no bem-estar no trabalho quanto aos afetos positivos e negativos e à realização profissional de trabalhadores em processos de mudança organizacional.

Originalidade/valor: A mudança organizacional é um processo dinâmico, constituído por meio das relações, em um contexto de incertezas. O mapeamento das relações pode auxiliar na compreensão dos fluxos de informação e na avaliação da disponibilidade de recursos.

Design/metodologia/abordagem: Participaram 151 profissionais de uma holding de transportes rodoviários que passa por mudanças no escopo dos serviços e no desenho organizacional. Mapearam-se laços de apoio, informação e confiança estabelecidos em função dos processos de mudança. Associada ao mapeamento, utilizou-se a Escala de Bem-Estar no Trabalho. Para análise, adotaram-se estatísticas descritivas e regressões múltiplas na construção de modelos explicativos para as dimensões de bem-estar no trabalho: realização e afetos positivos e negativos. 
Resultados: Variáveis em análise de redes sociais (ARS) de apoio e informação compuseram o modelo preditivo de bem-estar nos três modelos. Os laços de apoio e informação integraram o modelo preditivo de bem-estar. As métricas que revelam a quantidade de vezes que o colaborador é indicado e indica outros, a proximidade de vizinhos muito citados, a participação em subgrupos coesos e o grau em que assume posição central nestes são as posições dos atores capazes de predizer bem-estar. A influência do padrão de interação entre gestores e colaboradores deve ser considerada na promoção de bem-estar em organizações em processo de mudança.

\section{PALAVRAS-CHAVE}

Mudança nas organizações. Análise de redes sociais. Bem-estar no trabalho. Rede de apoio. Rede de informação.

\section{REFERENCES}

Ajilore, O. (2015). Identifying peer effects using spatial analysis: The role of peers on risky sexual behavior. Review of Economics of the Household, 13(3), 635-652. doi:10.1007/s11150-013-9235-4

Barrington, C., Latkin, C., Sweat, M. D., Moreno, L., Ellen, J., Kerrigan, D. (2009). Talking the talk, walking the walk: Social network norms, communication patterns, and condom use among the male partners of female sex workers in La Romana, Dominican Republic. Social Science \& Medicine, 68(11), 2037-2044. doi:10.1016/j.socscimed.2009.03.009

Bastian, M., Heymann, S., \& Jacomy, M. (2009). Gephi: An open source software for exploring and manipulating networks. Third International AAAI Conference on Weblogs and Social Media, San Jose, CA, USA.

Battilana, J., \& Casciaro, T. (2013). Overcoming resistance to organizational change: Strong ties and affective cooptation. Management Science, 59(4), 819-836.

Borgatti, S. P., Everett, M. G., \& Johnson, J. C. (2013). Analyzing social networks. Thousand Oaks, CA: Sage. 
Borgatti, S. P., \& Halgin, D. S. (2011). Analyzing affiliation networks. In P. J. Carrington \& J. Scott (Eds.), The Sage handbook of social network analysis (pp. 417-433). Thousand Oaks, CA: Sage.

Borgatti, S. P., \& Lopez-Kidwell, V. (2011). Network theory. In P. J. Carrington \& J. Scott (Eds.), The Sage handbook of social network analysis (pp. 40-51). Los Angeles: Sage.

Borgatti, S. P., Mehra, A., Brass, D. J., \& Labianca, G. (2009). Network analysis in the social sciences. Science, 323(5916), 892-895.

Brands, R. A. (2013). Cognitive social structures in social network research: A review. Journal of Organizational Behavior, 34, S82-S103. doi:10.1002/ job. 1890

Burt, R. S. \& Merluzzi, J. (2014). Embedded brokerage: Hubs versus locals. In D. J. Brass, G. Labianca, A. Mehra, D. S. Halgin, \& S. P. Borgatti (Eds.), Contemporary perspectives on organizational social networks (pp. 161-177). Bingley, UK: Emerald Group Publishing.

Choi, M. (2011). Employees' attitudes toward organizational change: A literature review. Human Resource Management, 50(4), 479-500.

Conde, R. de N. C., \& Farias, M. C., Filho (2016). Informal relations influenced by formal structure: A social network analysis managers. Revista de Ciências da Administração, 18(46), 68-81.

Cross, R. L., Singer, J., Colella, S., Thomas, R. J., \& Silverstone, Y. (2010). The organizational network fieldbook: Best practices, techniques and exercises to drive organizational innovation and performance. New York: John Wiley \& Sons.

Cross, R., Kaše, R., Kilduff, M., \& King, Z. (2013). Bridging the gap between research and practice in organizational network analysis: A conversation between Rob Cross and Martin Kilduff. Human Resources Management, 52, 627-644.

Dabos, G. E., \& Rousseau, D. M. (2013). Psychological contracts and informal networks in organizations: The effects of social status and local ties. Human Resource Management, 52(4), 485-510.

De, P., Cox, J., Boivin, J. F., Platt, R. W., \& Jolly, A. M. (2007). The importance of social networks in their association to drug equipment sharing among injection drug users: A review. Addiction, 102(11), 1730-1739. doi:10.1111/j.1360- 0443.2007.01936.x

Demo, G., \& Paschoal, T. (2016). Well-Being at Work Scale: Exploratory and confirmatory validation in the USA. Paidéia, 26(63), 35-43. 
Dokko, G., Kane, A., \& Tortoriello, M. (2014). One of us or one of my friends: How social identity and tie strength shape the creative generativity of boundary-spanning ties. Organization Studies, 35(5), 703-726.

Everett, M. G., \& Valente, T. W. (2016). Bridging, brokerage and betweenness. Social Networks, 44, 202-208.

Franco, K. S., Neiva, E. R., Nery, V. D. F., \& Demo, G. (2016). The relationship between context, attitudes and well-being in organizational change. Psicologia: Teoria e Pesquisa, 32 (Special Issue), 1-10.

Freeman, L. C. (2011). The development of social network analysis: With an emphasis on recent events. In P. J. Carrington \& J. Scott (Eds.), The Sage handbook of social network analysis (pp. 40-54). London: Sage.

Fuller, J., Kelly, B., Sartore, G., Fragar, L., Tonna, A., Pollard, G., \& Hazell, T. (2007). Use of social network analysis to describe service links for farmers' mental health. The Australian Journal of Rural Health, 15, 99-106. doi:10.11 11/j.1440-1584.2007.00861.x

Gubbins, C., \& Dooley, L. (2014). Exploring social network dynamics driving knowledge management for innovation. Journal of Management Inquiry, 23(2), 162-185.

Hanneman, R. A., \& Riddle, M. (2011). Concepts and measures for basic network analysis. In P. J. Carrington \& J. Scott (Eds.), The Sage handbook of social network analysis (pp. 340-369). London: Sage.

Jian, G. (2011). Articulating circumstance, identity and practice: Toward a discursive framework of organizational changing. Organization, 18(1), 45-64. doi:10.1177/1350508410373672

Katona, Z., Zubcsek, P. P., \& Sarvary, M. (2011). Network effects and personal influences: The diffusion of an online social network. Journal of Marketing Research, 48(3), 425-443.

Kehoe, R. R., \& Wright P. M. (2013). The impact of high performance human resource practices on employees' attitudes and behaviors. Journal of Management, 39, 366-391.

Khatoon, S., \& Farooq, A. (2014). Employees' attitude toward change and organizational performance. Prestige International Journal of Management and Research, 7(2-1), 347-353.

Labianca, G., \& Brass, D. J. (2006). Exploring the social ledger: Negative relationships and negative asymmetry in social networks in organizations. The Academy of Management Review, 31(3), 596-614. doi:10.5465/AMR. 2006.21318920 
Lü, L., Chen, D., Ren, X. L., Zhang, Q. M., Zhang, Y. C., \& Zhou, T. (2016). Vital nodes identification in complex networks. Physics Reports, 650, 1-63.

Luria, G., \& Kalish, Y. (2013). A social network approach to peer assessment: Improving predictive validity. Human Resource Management, 52 (4), 537-560.

Lysova, E., Richardson, J., Khapova, S., \& Jansen, P. (2015). Change-supportive employee behavior: A career identity explanation. Career Development International, 20(1), 38-62.

Macambira, M. O., Bastos, A. V. B., \& Rossoni, L. (2015). Redes sociais e o vínculo com a organização: Como a estrutura das relações explica o comprometimento, o entrincheiramento e o consentimento. Revista Psicologia: Organizações e Trabalho, 15(2), 109-122.

Maciel, C. O., \& Chaves, C. E. L.(2017). Informational status in intra-organizational networks: The role of knowledge sharing and structural holes. Revista de Administração, 52(2), 189-198.

Marchand, A., Demers, A., \& Durand, P. (2005). Do occupation and work conditions really matter? A longitudinal analysis of psychological distress experiences among Canadian workers. Sociology of Health and Illness, 27(5), 602-627. doi:10.1111/j.1467-9566.2005.00458.x

Mulawa, M., Yamanis, T. J., Hill, L. M., Balvanz, P., Kajula, L. J., \& Maman, S. (2016). Evidence of social network influence on multiple HIV risk behaviors and normative beliefs among young Tanzanian men. Social Science \& Medicine, 153, 35-43. doi:10.1016/j.socscimed.2016.02.002

Neiva, E. R., \& Paz, M. T. (2012). Percepção de mudança individual e organizacional: O papel das atitudes, dos valores, do poder e da capacidade organizacional. Revista de Administração, 47(1), 22-37. doi:10.5700/rausp1023

Newman, M. E. (2006). Modularity and community structure in networks. Proceedings of the National Academy of Sciences, 103(23), 8577-8582.

Paschoal, T., \& Tamayo, A. (2008). Construção e validação da Escala de Bem-Estar no Trabalho. Avaliação Psicológica, 7(1), 11-22.

Pichault, F., \& Schoenaers, F. (2003). HRM practices in a process of organizational change: A contextualist perspective. Applied Psychology, 52(1), 120-143.

Ribeiro, E., Macambira, M., \& Neiva, E. R. (2017). Social network analysis in organizations as a management support tool. In E. R. Neiva, C. V. Torres, $\&$ H. Mendonça (Eds.), Organizational psychology and evidence-based management (pp. 243-265). Cham: Springer.

Schreyögg, G., \& Sydow, J. (2011). Organizational path dependence: A process view. Organization Studies, 32(3), 321-335. 
Soltis, S. M., Agneessens, F., Sasovova, A., \& Labianca, G. (2013). A social network perspective on turnover intentions: The role of distributive justice and social support. Human Resources Management, 52(4), 561-584.

Tabachnick, B. G., \& Fidell, L. S. (2013). Using multivariate statistics (6th ed.). Boston: Pearson.

Teixeira, J. E. N. F., \& Verhine, R. E. (2014). Mudança organizacional em sistemas educacionais: Uma compreensão à luz da análise de redes sociais. Educação, 37(1), 81-91.

Tenkasi, R., \& Chesmore, M. C. (2003). Social networks and planned organizational change: The impact of strong ties on effective change implementation and use. The Journal of Applied Behavioral Science, 39(3), 281-300.

Vassilev, I., Rogers, A., Blickem, C., Brooks, H., Kapadia, D., ... \& Reeves, D. (2013). Social networks, the "work" and work force of chronic illness selfmanagement: A survey analysis of personal communities. PLoS ONE, 8(4), e59723. doi:10.1371/journal.pone.0059723

Wang, X. (2016). Subjective well-being associated with size of social network and social support of elderly. Journal of Health Psychology, 21 (6), 1037-1042.

Wichmann, B. K., Carter, C. R., \& Kaufmann, L. (2015). How to become central in an informal social network: An investigation of the antecedents to network centrality in an environmental SCM initiative. Journal of Business Logistics, 36(1), 102-119. doi:10.1111/jbl.12079

Wong, S., \& Boh, W. F. (2014). The contingent effects of social network sparseness and centrality on managerial innovativeness. Journal of Management Studies, 51(7), 1180-1203. doi:10.1111/joms.12086

Woodman, R. W. (2014). The science of organizational change and the art of changing organizations. Journal of Applied Behavioral Science, 50, 463-477.

Yamanis, T. J., Fisher, J. C., Moody, J. W., \& Kajula, L. J. (2015). Young men's social network characteristics and associations with sexual partnership concurrency in Tanzania. AIDS and Behavior, 20, 1244-1255. doi:10.1007/ s10461-015-1152-5

\section{AUTHOR NOTES}

Elisa M. B. A. Ribeiro, Ph.D. from the Postgraduate Program in Psychology, Federal University of Bahia (UFBA); Elaine R. Neiva, Ph.D. from the Postgraduate Program in Psychology, University of Brasília (UnB); Magno O. Macambira, Ph.D. from the Postgraduate Program in Psychology, Federal University of Bahia (UFBA); Leonardo F. Martins, Ph.D. from the Postgraduate Program in Psychology, Federal University of Juiz de Fora (UFJF). 


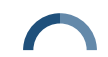

Elisa M. B. Amorim-Ribeiro, Elaine R. Neiva, Magno O. Macambira, Leonardo F. Martins

Elisa M. B. A. Ribeiro is now a professor at the Postgraduate Program in Social Psychology of Salgado de Oliveira University (Universo); Elaine R. Neiva is now an assistant professor 4 of Higher Education at the Postgraduate Program in Social, Work and Organization Psychology of UnB; Magno O. Macambira is now an assistant professor at the Department of Human Sciences and Philosophy (DCHF) of State University of Feira de Santana (Uefs); Leonardo F. Martins is now an assistant professor at the Postgraduate Program in Psychology of Universo.

Correspondence concerning this article should be addressed to Elisa M. B. A. Ribeiro, Rua Marechal Deodoro, 211, Universidade Salgado de Oliveira (Universo), Centro, Niterói, Rio de Janeiro, Brazil, CEP 24030-060.

E-mail: ribeiro.emba@gmail.com

\section{EDITORIAL BOARD}

Editor-in-chief

Gilberto Perez

Associate editor

Mary Sandra Carlotto

Technical support

Vitória Batista Santos Silva

\section{EDITORIAL PRODUCTION}

Publishing coordination

Jéssica Dametta

Language editor

Daniel de Almeida Leão

Layout designer

Emap

Graphic designer

Libro 